\title{
Expression of Structurally Unaltered Androgen Receptor in Extramammary Paget's Disease
}

\author{
Akihide Fujimoto, Minoru Takata, Naohito Hatta, and Kazuhiko Takehara \\ Department of Dermatology, Kanazawa University School of Medicine, Kanazawa, Japan
}

\begin{abstract}
SUMMARY: Extramammary Paget's disease (EMPD) is an uncommon neoplasm of the skin that shows differentiation to an apocrine sweat gland. Although we previously showed that erbB-2 overexpression may play a part in the progression of EMPD, molecular genetic defects underlying the development of EMPD are poorly understood. In the study described here, we examined androgen receptor expression and gene alterations in 30 cases of EMPD without internal malignancy. Immunohistochemistry revealed that 24 of $30(80 \%)$ cases of EMPD variably expressed nuclear androgen receptor. Semi-quantitation of receptor content by scoring immunostained sections showed no difference between in situ $(n=17)$ and invasive $(n=13)$ EMPD tumors. Androgen receptor expression was also observed in four of six lymph node metastases. In these lymph nodes, expression of androgen receptor mRNA was confirmed by reverse transcriptase-polymerase chain reaction. Direct sequencing of exon 2 through exon 8, which encodes DNA- and hormone-binding domains of the androgen receptor gene, revealed no mutation in any of the 10 advanced stage tumors. Neither amplification nor deletion of the androgen receptor gene locus was detected by dual color fluorescence in situ hybridization analysis in 14 tumors. The present findings showing frequent expression of structurally unaltered androgen receptor in an advanced stage of EMPD may provide a rational basis for hormone therapy, which is widely used in the treatment of metastatic prostate cancer and androgen receptor-positive breast cancer recurrence. (Lab Invest 2000, 80:1465-1471).
\end{abstract}

$E$ xtramammary Paget's disease (EMPD) is an uncommon neoplasm of apocrine gland-bearing skin, that most commonly involves the vulvar, perianal, perineal, scrotal, and penile regions (Heymann, 1993). Although it is rarely associated with underlying adenocarcinoma, it mostly begins as an intraepidermal adenocarcinoma that can invade the dermis and may metastasize via the lymphatic system (Feuer et al, 1990; Hart and Millman, 1977; Jones et al, 1979; Murata et al, 1999). The histogenesis of EMPD has long been disputed. Emerging information, however, supports the concepts that Paget's cells in EMPD are of glandular origin, usually showing apocrine differentiation and that the disease may arise from a pluripotential epidermal precursor (Guarner et al, 1989; Mazoujian et al, 1984; Roth et al, 1977).

The molecular genetic defects underlying EMPD are poorly understood. We previously showed that erbB-2 overexpression by either gene amplification or transcriptional activation may play a part in the progression of EMPD (Takata et al, 1999). However, other molecular genetic defects, including p53 mutations, allelic loss of several selected chromosome arms as

Received July 3, 2000.

This study was supported by a Grant-in-Aid for Scientific Research (C-2) (Grant No. 0.12670811) from the Ministry of Education, Science, Culture and Sports of Japan.

Address reprint requests to: Dr. Minoru Takata, Department of Dermatology, Kanazawa University School of Medicine, 13-1 Takara-machi, Kanazawa 920-8641, Japan. Fax: 8176234 4270; E-mail: takata@ med.kanazawa-u.ac.jp well as abnormal activation of the $\beta$-catenin gene, which are commonly seen in other epithelial malignancies, were not detected in EMPD (Takata et al, 1999; Takata et al, 1997). To explore further the molecular pathogenesis of EMPD, we aimed at examining androgen receptor expression in Paget's cells of EMPD for several reasons. Firstly, tumor cells in EMPD show differentiation to apocrine sweat glands(Guarner et al, 1989), which normally express androgen receptor (Blauer et al, 1991; Choudhry et al, 1992; Kurata et al, 1990). Secondly, the androgen receptor is a liganddependent transcriptional factor that regulates tissuespecific genes involved in cellular proliferation and differentiation (Cude et al, 1999). Thirdly, the action of androgens and other hormones via the androgen receptor is well documented in the development and growth of carcinomas derived from other exocrine glands such as the prostate and the breast (Hackenberg and Schulz, 1996; Kallioniemi and Visakorpi, 1996). Finally, stimulation of growth by androgen with androgen receptors was actually demonstrated in a transplantable tumor line established in nude mice from human EMPD (Nishi et al, 1992). In the study described here, we examined by immunohistochemistry and reverse transcriptase-polymerase chain reaction (RT-PCR) the expression of androgen receptors in 30 cases of EMPD without associated internal malignancy. Furthermore, androgen receptor gene mutation and amplification, both of which were implicated in the progression of prostate cancer (Taplin et al, 1995; Visakorpi et al, 1995), were examined in selected EMPD tumors. 


\section{Results}

As expected, immunohistochemical staining of normal axillary skin showed nuclear expression of androgen receptor in secretory cells of apocrine glands, seboblasts, and sebocytes of sebaceous glands, luminal epithelial cells of eccrine sweat glands, smooth muscle cells, and the cells of dermal papillae in hair follicles. Although epidermal basal cells, dermal fibroblasts, and endothelial cells were reported to be positive for androgen receptor in a previous study using polyclonal or monoclonal antibody on frozen tissue sections (Blauer et al, 1991; Choudhry et al,
1992), we could not confirm androgen receptor expression in these cell types. No staining of androgen receptor was observed in normal lymph nodes.

As shown in Table 1 and Figure 1, 24 of 30 (80\%) samples of EMPD excised from both male and female patients expressed androgen receptor, whereas 2 of 17 in situ EMPD and 4 of 13 invasive EMPD carcinomas completely lacked androgen receptor expression. Four of six cases of lymph node metastasis also showed positive androgen receptor staining, and in three cases most of the tumor cells strongly expressed androgen receptor. Expression was predom-

Table 1. Androgen Receptor Expression and Gene Alterations in Extramammary Paget's Disease

\begin{tabular}{|c|c|c|c|c|c|c|c|c|}
\hline \multirow[b]{2}{*}{$\begin{array}{c}\text { Case } \\
\text { No. }\end{array}$} & \multirow[b]{2}{*}{$\begin{array}{c}\text { Age/ } \\
\text { sex }\end{array}$} & \multirow[b]{2}{*}{ Tumor $^{a}$} & \multicolumn{3}{|c|}{ Immunohistochemistry $^{b}$} & \multirow[b]{2}{*}{$\mathrm{RT}^{-\mathrm{PCR}^{c}}$} & \multirow[b]{2}{*}{$\mathrm{FISH}^{c}$} & \multirow[b]{2}{*}{ Sequencing ${ }^{\circ}$} \\
\hline & & & $\begin{array}{l}\% \text { of } \\
\text { tumor } \\
\text { cells } \\
\text { stained }\end{array}$ & $\begin{array}{l}\text { Intensity } \\
\text { of } \\
\text { staining }\end{array}$ & $\begin{array}{c}\text { AR } \\
\text { score }\end{array}$ & & & \\
\hline 1 & $86 / F$ & In situ & 2 & 2 & 4 & NE & NE & NE \\
\hline 2 & $80 / \mathrm{M}$ & In situ & 1 & 1 & 2 & NE & NE & NE \\
\hline 3 & $72 / \mathrm{M}$ & In situ & 1 & 1 & 2 & NE & NE & NE \\
\hline 4 & 70/F & In situ & 3 & 2 & 5 & NE & NE & NE \\
\hline 5 & $72 / \mathrm{F}$ & In situ & 1 & 2 & 3 & NE & NE & NE \\
\hline 6 & $71 / \mathrm{M}$ & In situ & 3 & 2 & 5 & $\mathrm{NE}$ & NE & $\mathrm{NE}$ \\
\hline 7 & 72/M & In situ & 2 & 3 & 5 & NE & NCN & NE \\
\hline 8 & $5 / F$ & In situ & 3 & 2 & 5 & NE & $\mathrm{NE}$ & NE \\
\hline 9 & $75 / \mathrm{M}$ & In situ & 4 & 1 & 5 & NE & NE & NE \\
\hline 10 & $71 / \mathrm{M}$ & In situ & 0 & 0 & 0 & NE & $\mathrm{NE}$ & NE \\
\hline 11 & $52 / \mathrm{F}$ & In situ & 3 & 3 & 6 & $\mathrm{NE}$ & NCN & $\mathrm{NE}$ \\
\hline 12 & $68 / \mathrm{M}$ & In situ & 0 & 0 & 0 & NE & $\mathrm{NE}$ & NE \\
\hline 13 & 70/M & In situ & 2 & 2 & 4 & NE & $\mathrm{NE}$ & NE \\
\hline 14 & $63 / \mathrm{M}$ & In situ & 3 & 3 & 6 & NE & NCN & NE \\
\hline 15 & $67 / F$ & In situ & 1 & 1 & 2 & NE & $\mathrm{NE}$ & NE \\
\hline 16 & $76 / \mathrm{F}$ & In situ & 1 & 1 & 2 & $\mathrm{NE}$ & $\mathrm{NE}$ & NE \\
\hline 17 & $77 / \mathrm{F}$ & In situ, $\mathrm{R}$ & 4 & 3 & 7 & NE & NCN & NE \\
\hline 18 & $48 / \mathrm{M}$ & Invasive & 2 & 2 & 4 & NE & $\mathrm{NE}$ & NE \\
\hline 19 & $78 / \mathrm{M}$ & Invasive & 2 & 2 & 4 & NE & NCN & NE \\
\hline 20 & $84 / \mathrm{M}$ & Invasive & 1 & 1 & 2 & NE & $\mathrm{NE}$ & NE \\
\hline 21 & 70/M & Invasive & 1 & 2 & 3 & NE & NCN & NE \\
\hline 22 & $76 / \mathrm{M}$ & Invasive & 0 & 0 & 0 & NE & $\mathrm{NE}$ & wild-type \\
\hline 23 & 78/M & Invasive & 0 & 0 & 0 & NE & NCN & wild-type \\
\hline 24 & $58 / \mathrm{M}$ & Invasive & 1 & 1 & 2 & NE & NCN & wild-type \\
\hline \multirow[t]{2}{*}{25} & $63 / \mathrm{M}$ & Invasive & 0 & 0 & 0 & NE & NE & $\mathrm{NE}$ \\
\hline & & LN meta & 0 & 0 & 0 & $\mathrm{NE}$ & NE & NE \\
\hline \multirow[t]{2}{*}{26} & $76 / \mathrm{M}$ & Invasive & 1 & 2 & 3 & NE & NA & wild-type \\
\hline & & LN meta & 1 & 1 & 2 & + & NA & wild-type \\
\hline \multirow[t]{2}{*}{27} & $64 / M$ & Invasive & 4 & 1 & 5 & NE & NCN & $\mathrm{NE}$ \\
\hline & & LN meta & 4 & 3 & 7 & + & NCN & wild-type \\
\hline \multirow[t]{2}{*}{28} & $72 / \mathrm{M}$ & Invasive & 0 & 0 & 0 & $\mathrm{NE}$ & NCN & wild-type \\
\hline & & LN meta & 0 & 0 & 0 & - & NA & $\mathrm{NE}$ \\
\hline \multirow[t]{2}{*}{29} & 78/M & Invasive & 4 & 3 & 7 & NE & $\mathrm{NE}$ & NE \\
\hline & & LN meta & 4 & 3 & 7 & + & NCN & wild-type \\
\hline \multirow[t]{2}{*}{30} & 72/M & Invasive & 4 & 3 & 7 & NE & NCN & wild-type \\
\hline & & LN meta & 4 & 3 & 7 & + & NA & wild-type \\
\hline
\end{tabular}

${ }^{a}$ In situ, in situ primary tumor; In situ, R, recurrent in situ tumor; Invasive, invasive primary tumor; LN meta, lymph node metastasis.

${ }^{b}$ AR score is a sum of percentage of tumor cells stained ( 0 , no staining; 1 , less than $\left.25 \% ; 2,26 \%-50 \% ; 3,51 \%-75 \% ; 4,76 \%-100 \%\right)$ and the staining intensity (0, absent; 1 , weak; 2 , moderate; 3 , strong).

${ }^{c} \mathrm{NE}$, not examined; NCN, normal copy number; NA, not applicable. 

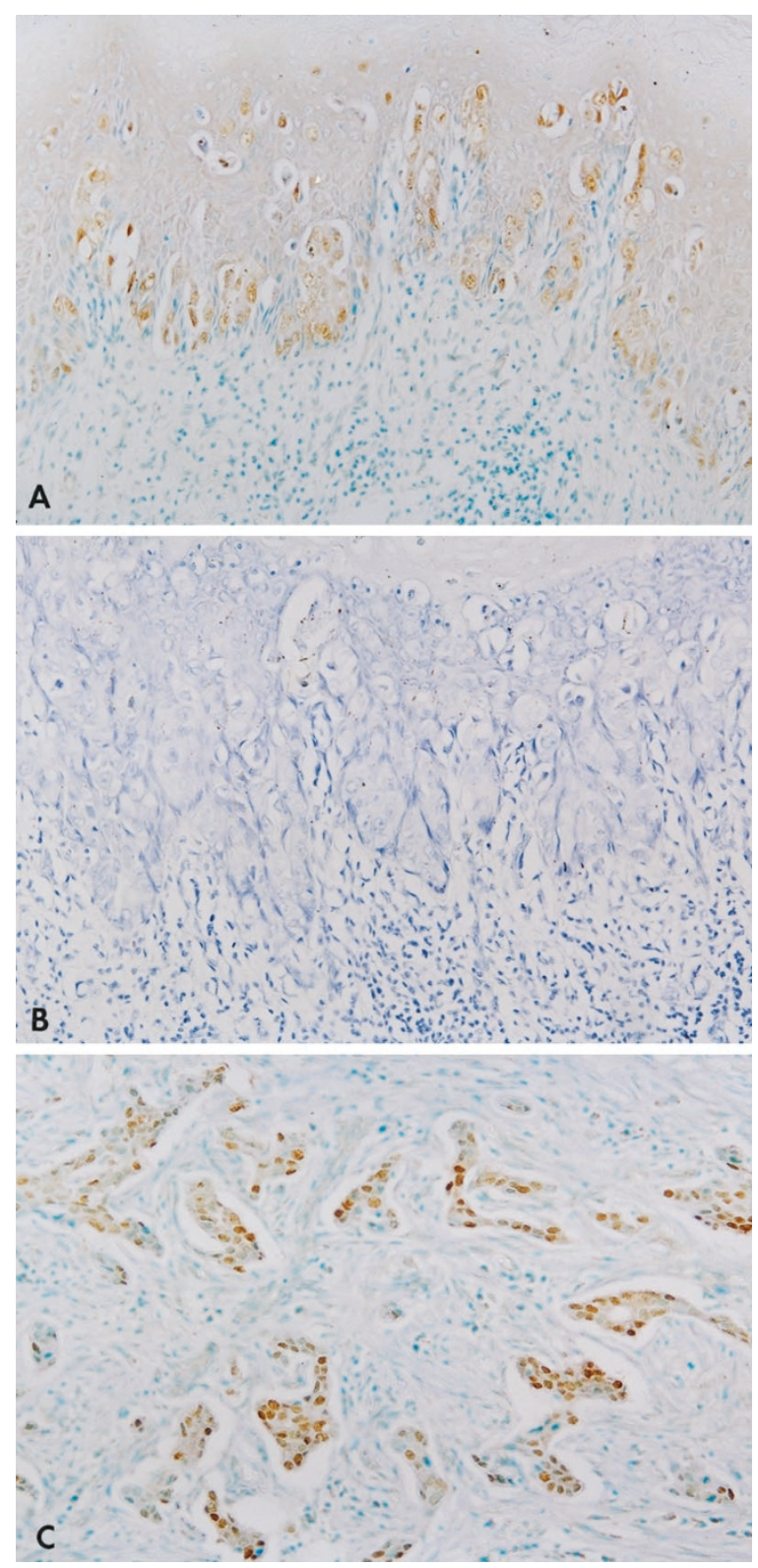

\section{Figure 1.}

Immunoperoxidase staining of androgen receptor in EMPD. A, Distinct nuclear staining of Paget's cells in in situ carcinoma (Case 17, biotin-streptavidin method counterstained with methyl green; original magnification, $\times 50) . B$, Negative control specimen counterstained with hematoxylin (Case 17; original magnification, $\times 50)$. $C$, Strong nuclear expression of androgen receptor in lymph node metasasis (Case 24, biotin-streptavidin method counterstained with methyl green; original magnification, $\times 57$ ).

inantly nuclear in all positive cases and was frequently associated with weak diffuse cytoplasmic staining. No staining was observed in negative control specimens in which the primary antibody was replaced by normal mouse serum. Semi-quantitative scoring of androgen receptor content in immunostained sections was variable, ranging from 2 (minimum) to 7 (maximal), in both in situ and invasive tumors. There was no statistically significant difference in mean androgen receptor scores between in situ and invasive EMPD (mean \pm SEM, $3.7 \pm 0.5$ and $2.8 \pm 0.7$, respectively; $p=0.31$ ).
To confirm androgen receptor expression in tumor cells of EMPD, we carried out RT-PCR analysis using a primer pair spanning exon 1 through exon 3 of the androgen receptor gene. Since normal genital skin contains various cellular components that express androgen receptor (Blauer et al, 1991; Choudhry et al, 1992), we examined expression of androgen receptor mRNA in lymph node samples. As shown in Figure 2, $\mathrm{LNCaP}$ cell and 4 metastases that expressed androgen receptor protein showed androgen receptor transcripts with the expected size of $365 \mathrm{bp}$. The identity of the PCR product was confirmed by direct DNA sequencing (data not shown). In contrast, no amplification was detected in one metastasis (Case 28) that was completely negative by immunohistochemistry. Five cDNA samples isolated from normal lymph nodes did not yield amplified products.

To clarify whether the amplification of the androgen receptor gene was involved in the development of EMPD, dual-color fluorescence in situ hybridization (FISH) was performed in 4 in situ carcinomas that were intensely labeled with anti-androgen receptor antibody and in 10 advanced-stage tumors (5 primaries and 5 metastases) that variably expressed androgen receptor. In addition, three androgen receptornegative tumors (Cases 23 and 28) were also examined, to clarify whether the lack of expression was caused by the gene deletion. The procedure was successful in 13 specimens, whereas the remaining 4 specimens were not applicable because hybridization signals were completely absent even in the keratinocytes or lymphocytes that served as internal positive controls. In all 13 tumors in which hybridization was successful, most tumor cells showed hybridized signals. The tumor specimens excised from male patients showed one red signal of the androgen receptor gene locus, which was associated with one green centromeric signal, whereas two red and two green spots were respectively detected in tumor cells excised from

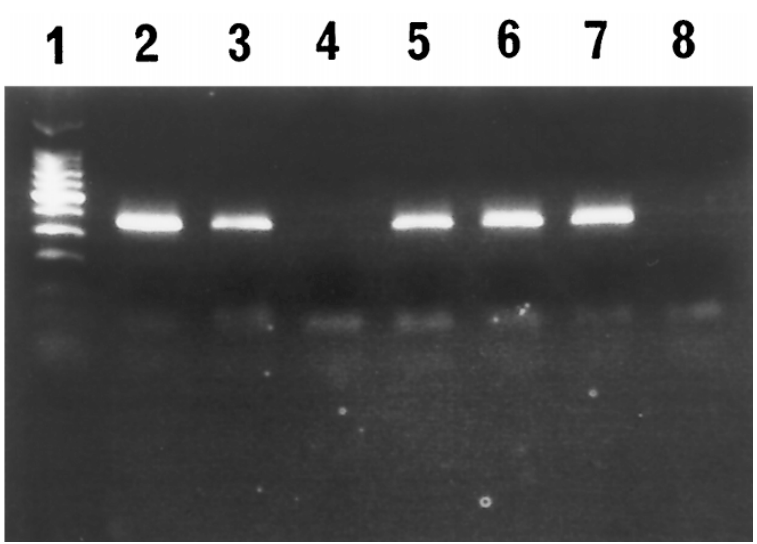

Figure 2.

Reverse transcriptase-polymerase chain reaction (RT-PCR) showing androgen receptor mRNA expression in lymph node metastasis of EMPD. Molecular size marker (lane 1), prostate carcinoma cell line LNCaP (lane 2), lymph node metastasis from Cases 26-30 (lanes 3-7) and normal lymph node (negative control) (lane 8). All lymph node samples from EMPD, except one tumor (Case 28 , lane 4), which were completely negative by immunohistochemistry, express MRNA for androgen receptor. 
female patients (Fig. 3). Neither increase nor decrease in the numbers of red signals relative to green signals was observed in any tumor (Table 1).

Finally, we studied the integrity of the androgen receptor gene in 10 tumors excised from 8 advancedstage cases of EMPD, because mutations of the androgen receptor gene may confer a growth advantage in prostate cancer (Gaddipati et al, 1994; Newmark et al, 1992; Taplin et al, 1995; Tilley et al, 1996) as well as in male breast cancer (Lobaccaro et al, 1993). Exons 2 to 8 of the androgen receptor gene were directly sequenced. However, in none of the 10 DNA samples analyzed could a mutation be detected. Exon 1 of the androgen receptor gene was not examined because of its large size and infrequent mutations in prostate cancer (Gottlieb et al, 1998).

\section{Discussion}

The hormone dependency of EMPD and possible indication of hormone therapy for the treatment of EMPD was first suggested by Nishi et al (1992), who established a transplantable tumor, EMP-K1, in the nude mouse from skin metastasis of EMPD. The growth of the EMP-K1 tumor in castrated nude mice was stimulated by injections of testosterone, dihydrotestosterone, diethylstilbestrol, and $17 \beta$-estradiol, indicating that this transplantable tumor line was hormone dependent. Furthermore, functional receptor assay showed that the EMP-K1 tumor line expressed androgen and estrogen, as well as progesterone receptors, although the affinity of hormone binding sites to androgen receptor was 23-fold and 6-fold greater than that of estrogen and progesterone receptors, respectively (Nishi et al, 1992). However, immunohistochemical studies examining a number of EMPD tumors did not detect the expression of estrogen and progesterone receptors in Paget's cell of EMPD (Imakado et al, 1999; Lloveras et al, 1991; Swanson et al, 1991). However, the present study showed that $80 \%$ of the 30 EMPD tumors variably expressed androgen receptor. The mRNA expression of the an-

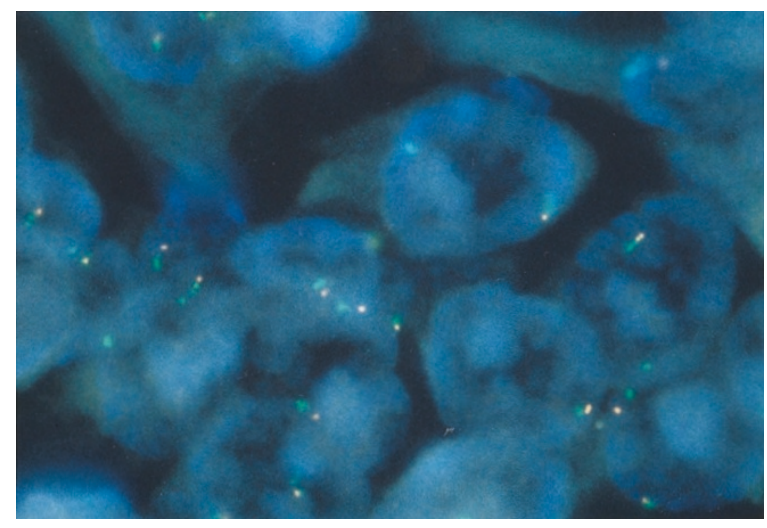

Figure 3.

Interphase FISH analysis of primary tumor (Case 27) with probes for the androgen receptor (orange) gene and DXZ1 (green). One copy of both androgen receptor and DXZ1 is seen in most tumor cells, indicating no androgen receptor amplification. drogen receptor gene was also confirmed in four lymph node metastases by RT-PCR. Very recently, Diaz de Leon et al (2000), by using immunohistochemical methods, also reported that 15 of 28 EMPD expressed androgen receptor, whereas all cases lacked detectable estrogen and progesterone receptors. These findings strongly suggest that androgen receptor, rather than estrogen and progesterone receptors, is the most important hormone receptor responsible for the development and growth of EMPD. The role of estrogen and progesterone via their respective receptors in EMPD, as demonstrated in EMP-K1 tumor (Nishi et al, 1992), is unknown. Given the negative expression of these female hormone receptors in a number of EMPD tumors (Imakado et al, 1999; Lloveras et al, 1991; Swanson et al, 1991), the EMP-K1 tumor may have been simply an exception. Alternatively, negative immunohistochemical results may reflect the much lower amount of these female hormone receptor proteins expressed in tumor cells compared with androgen receptor as was the case in the EMP-K1 tumor (Nishi et al, 1992).

Nevertheless, $20 \%$ of EMPD cases in our series were devoid of androgen receptor expression as determined by immunohistochemistry. As shown in the results in Case 28 (Table 1), absent expression of mRNA with a structurally normal androgen receptor gene (neither deletion nor mutation) suggests that loss of expression of androgen receptor is most likely due to transcriptional repression. Similarly, FISH analysis showing no deletion of androgen receptor gene locus in tumors that heterogeneously expressed androgen receptor (eg, Cases 19, 21, and 24) suggests that the transcriptional status of the androgen receptor gene in individual tumor cells was heterogeneous in a given tumor.

In prostate cancer, mutations of the androgen receptor gene leading to activation of androgen receptor by other steroids and paradoxically also by antiandrogens are not uncommon in recurrent tumors after androgen deprivation therapy (Gaddipati et al, 1994; Suzuki et al, 1993; Taplin et al, 1995). Furthermore, androgen receptor gene mutations have also been found in localized or latent prostate cancer before hormonal therapy (Newmark et al, 1992; Takahashi et al, 1995; Tilley et al, 1996), suggesting that mutant androgen receptor might provide a growth advantage even in the presence of a normal androgen level. Thus, we examined exons 2 to 8 encoding DNAand hormone-binding domains of the androgen receptor gene by direct sequencing in 10 advanced EMPD tumors. However, no mutations were found in any tumor, indicating that mutations of the androgen receptor gene, which could affect the structure of DNAand hormone-binding domains, do not contribute to the progressive growth of these EMPD tumors. There remains a possibility, however, that mutations in the transactivation domain of the androgen receptor might be involved in EMPD, because we did not examine exon 1, which encodes the transactivation domain consisting of over 500 amino acids, and because one study in prostate cancer reported rela- 
tively frequent alterations in this exon (Tilley et al, 1996).

Amplification of the androgen receptor gene is another important mechanism of hormone independence and recurrence in prostate cancer after androgen deprivation therapy (Koivisto et al, 1997; Visakorpi et al, 1995). Although this gene alteration was not detected in prostate cancer before hormone therapy (Koivisto et al, 1997), we examined possible androgen receptor gene amplification in selected cases of EMPD by FISH. However, no amplification was detected in any tumor.

Although in situ or minimally invasive EMPD can be cured by conventional surgical management (Goldblum and Hart, 1997; Zollo and Zeitouni, 2000), deeply invasive carcinoma behaves as a fully malignant adenocarcinoma that is resistant to chemotherapy (Coonley et al, 1985; Yamazaki et al, 1999). No standard treatment protocol has been established for metastatic EMPD (Yamazaki et al, 1999). However, the findings of the present study showing the expression of structurally normal androgen receptor in invasive primary tumors and lymph node metastasis of EMPD may provide a rational basis for hormone therapy for this rare skin cancer. For male patients, maximum androgen blockade therapy, which is widely used for advanced prostate cancer (Caubet et al, 1997), would be a treatment of choice. Medroxyprogesterone acetate therapy, which is effective for androgen receptorpositive advanced breast cancer (Birrell et al, 1995), might be considered for female patients. Future clinical trials are necessary to establish a hormone therapy as a standard treatment for advanced EMPD.

\section{Materials and Methods}

\section{Patients and Tissue Samples}

Surgical specimens were obtained from 30 patients with EMPD (23 men and 7 women). Seventeen patients had in situ carcinoma, and the remaining 13 patients had invasive carcinoma, eight of which were associated with distant and/or lymph node metastases. None of the cases were associated with underlying genitourinary or gastrointestinal malignancies. Paraffin-embedded tissue blocks of all 30 cutaneous lesions and 6 lymph node metastases were available. In addition, fresh frozen tumor samples were obtained from 8 patients, and these samples were used for RT-PCR and sequencing analyses.

\section{Immunohistochemistry}

Paraffin sections $4 \mu \mathrm{m}$ thick were cut from each block and mounted on silanized glass slides. Prior to staining, the deparaffinized sections were soaked in sodium citrate buffer $\left(\mathrm{pH}\right.$ 6.0) preheated at $95^{\circ}$ to $99^{\circ} \mathrm{C}$ for 10 minutes. Then the sections were reacted with antihuman androgen receptor monoclonal antibody AR441 (1:50) (DAKO, Carpinteria, California), which was raised against synthetic peptide corresponding to amino acids 229-315 of the human androgen receptor, at $4^{\circ} \mathrm{C}$ overnight. Binding of the primary antibody was detected by sequential 30-minute incubations with biotinylated rabbit antimouse immunoglobulins and a streptavidin-biotin peroxidase complex (Histofine Kit; Nichirei, Tokyo, Japan). Reaction products were visualized with diaminobenzidine, and the sections were counterstained with methyl green. The specificity of the immunoreaction was verified by staining normal human axillar skin sections containing apocrine glands as a positive control and normal lymph node tissues as a negative control. The specificity of the antibody was also verified by replacing the primary antibody with normal mouse serum. To roughly measure quantitatively androgen receptor content, a score corresponding to the sum of the percentage of tumor cells stained $(0$, no staining; 1 , less than $25 \%$; 2, 26\%-50\%; 3, 51\%-75\%; 4, 76\%$100 \%)$ and the staining intensity (0, absent; 1 , weak; 2 , moderate; 3, strong) was established (Chodak et al, 1992). Scoring was carried out independently by two observers and a consensus reached when results were discrepant.

\section{Isolation of RNA and RT-PCR}

Total RNA was isolated from five frozen lymph node metastases of EMPD by the acid guanidinium thiocyanate procedure (Isogen; Nippon Gene, Tokyo, Japan), and first strand cDNA synthesis was performed using an RNA PCR Kit (Takara, Tokyo, Japan), as described previously (Hatta et al, 1998). The quality of cDNA synthesis was monitored by PCR amplification using $\beta$-actin primers. cDNA from a prostate carcinoma cell line, LNCaP (Berns et al, 1986), was also used as a positive control. Five cDNA samples from normal lymph nodes obtained from melanoma patients who underwent elective lymphadenectomy (Hatta et al, 1998) were also used as negative controls.

RT-PCR was carried out as previously described (Taplin et al, 1995) with some modifications. One microliter of CDNA was amplified with sense (5'GCATGGTGAGCAGAGTGCCCTATC-3') and antisense primers (5'-TCCCAGAGTCATCCCTGCTTCAT$\left.3^{\prime}\right)$, which corresponded to the sequences of exons 1 and 3 , respectively. The PCR was performed in $50 \mu \mathrm{l}$ mixture consisting of $10 \mathrm{mM}$ Tris- $\mathrm{HCl}(\mathrm{pH} 8.3), 200 \mu \mathrm{M}$ of each dNTP, $50 \mathrm{mM} \mathrm{KCl}, 1.5 \mathrm{mM} \mathrm{MgCl}_{2}, 50 \mathrm{ng}$ of each oligonucleotide primer, and 1.25 units of AmpliTaq Gold DNA polymerase (Perkin Elmer, Branchburg, New Jersey). The PCR mixture was incubated in a thermal cycler at $95^{\circ} \mathrm{C}$ for 9 minutes for one cycle, at $94^{\circ} \mathrm{C}$ for 20 seconds, $55^{\circ} \mathrm{C}$ for 30 seconds, and $72^{\circ} \mathrm{C}$ for 1 minute for 40 cycles, and finally at $72^{\circ} \mathrm{C}$ for 10 minutes for one cycle. The amplified DNA samples were run on a $2.0 \%$ agarose gel, and bands were visualized with ethidium bromide.

\section{DNA Sequencing}

A total of 10 invasive primary tumors or lymph node metastases excised from 8 patients were examined for androgen receptor gene mutations by direct sequencing. Tumor tissue was isolated from 5 to 10 
consecutive $6 \mu \mathrm{m}$ frozen tissue sections by microdissection, and genomic DNA was isolated according to standard methods by proteinase $\mathrm{K}$ digestion and phenol-chloroform extraction (Takata et al, 1997). Exons 2 to 8 of the androgen receptor gene were amplified using primers and PCR conditions as described previously (Tilley et al, 1996). Annealing temperatures for each exon were as follows: $60^{\circ} \mathrm{C}$ for exons 2,7 , and $8 ; 53^{\circ} \mathrm{C}$ for exons 3 and $4-1 ; 58^{\circ} \mathrm{C}$ for exon $4-2 ; 63^{\circ} \mathrm{C}$ for exon 5 ; and $55^{\circ} \mathrm{C}$ for exon 6 . The PCR products were purified using DNA affinity spin columns (Wizard PCR Preps; Promega, Madison, Wisconsin) and directly sequenced by automated sequencing with fluorescently labeled dideoxy chainterminating nucleotides and Taq DNA polymerase using a Dye Terminator Cycle Sequencing Ready Reaction Kit (Perkin Elmer, Foster City, California). Either sense or antisense primer was used as a sequencing primer in each exon and whenever equivocal sequencing was also carried out in reverse direction.

\section{Fluorescence In Situ Hybridization (FISH)}

To detect amplification of the androgen receptor gene, FISH was performed on paraffin embedded tissue sections employing a sensitive dual color method which was used previously for detecting erbB-2 gene amplification in EMPD (Takata et al, 1999). The sections adjacent to those used for immunostaining were mounted on glass slides and representative areas containing androgen receptor-expressing cells were selected for FISH analysis. Spectrum Orange LSI androgen receptor gene locus (Xq12) and Spectrum Green DXZ1 (Xp11.1-q11.1) probes were purchased from Vysis Inc. (Downers Grove, Illinois). Staining was carried out as described previously (Takata et al, 1999). Briefly, deparaffinized sections were incubated in $20 \%$ sodium bisulfite/2X standard saline citrate (SSC) at $43^{\circ} \mathrm{C}$ for 20 minutes. After washing in $2 \mathrm{X}$ $\mathrm{SSC}$, the tissues were digested with $25 \mathrm{ng} / \mathrm{ml}$ of proteinase K (Boehringer Mannheim, Mannheim, Germany) at $37^{\circ} \mathrm{C}$ for 30 minutes. After washing in $2 \mathrm{X}$ SCC and dehydration by passage through a graded ethanol series, the slides were dried and denatured with the probes on a hot plate at $69^{\circ} \mathrm{C}$ for 5 minutes and then hybridized overnight at $37^{\circ} \mathrm{C}$. After washing in $0.4 \% \mathrm{SSC} / 0.3 \% \mathrm{NP}-40$ solution at $75^{\circ} \mathrm{C}$ for 2 minutes and then rinsing with $2 \mathrm{X}$ SCC/0.1\% NP-40 solution at room temperature, the slides were counterstained with 4'6-diamidine 2'-phenylindole dihydrochloride (DAPI) in antifade solution (Oncor, Gaithersburg, Maryland) and examined with an epifluorescence microscope (Olympus, Tokyo, Japan) equipped with a triple band pass filter.

\section{Statistical Analysis}

Mean androgen receptor scores among the different stages of progression was determined by Student's t-test.

\section{Acknowledgements}

We thank Miss Yuko Yamada for excellent technical assistance in immunohistochemistry and Dr. Kiyoshi Koshida (Department of Urology, Kanazawa University) for providing LNCaP cDNA.

\section{References}

Berns EM, de Boer W, and Mulder E (1986). Androgendependent growth regulation of and release of specific protein(s) by the androgen receptor containing human prostate tumor cell line LNCaP. Prostate 9:247-259.

Birrell SN, Roder DM, Horsfall DJ, Bentel JM, and Tilley WD (1995). Medroxyprogesterone acetate therapy in advanced breast cancer: The predictive value of androgen receptor expression. J Clin Oncol 13:1572-1577.

Blauer M, Vaalasti A, Pauli SL, Ylikomi T, Joensuu T, and Tuohimaa $P$ (1991). Location of androgen receptor in human skin. J Invest Dermatol 97:264-268.

Caubet JF, Tosteson TD, Dong EW, Naylon EM, Whiting GW, Ernstoff MS, and Ross SD (1997). Maximum androgen blockade in advanced prostate cancer: A meta-analysis of published randomized controlled trials using nonsteroidal antiandrogens. Urology 49:71-78.

Chodak GW, Kranc DM, Puy LA, Takeda H, Johnson K, and Chang C (1992). Nuclear localization of androgen receptor in heterogeneous samples of normal, hyperplastic and neoplastic human prostate. J Urol 147:798-803.

Choudhry R, Hodgins MB, Van der Kwast TH, Brinkmann AO, and Boersma WJ (1992). Localization of androgen receptors in human skin by immunohistochemistry: Implications for the hormonal regulation of hair growth, sebaceous glands and sweat glands. J Endocrinol 133:467-475.

Coonley CJ, Schauer P, Kelsen DP, Sordillo P, and Huvos AG (1985). Chemotherapy of metastatic sweat gland carcinoma. A retrospective review. Am J Clin Oncol 8:307-311.

Cude KJ, Dixon SC, Guo Y, Lisella J, and Figg WD (1999). The androgen receptor: Genetic considerations in the development and treatment of prostate cancer. $\mathrm{J} \mathrm{Mol} \mathrm{Med} \mathrm{77:}$ 419-426.

Diaz de Leon E, Carcangiu ML, Prieto VG, McCue PA, Burchette JL, To G, Norris BA, Kovatich AJ, Sanchez RL, Krigman HR, and Gatalica Z (2000). Extramammary Paget disease is characterized by the consistent lack of estrogen and progesterone receptors but frequently expresses androgen receptor. Am J Clin Pathol 113:572-575.

Feuer GA, Shevchuk M, and Calanog A (1990). Vulvar Paget's disease: The need to exclude an invasive lesion. Gynecol Oncol 38:81-89.

Gaddipati JP, McLeod DG, Heidenberg HB, Sesterhenn IA, Finger MJ, Moul JW, and Srivastava S (1994). Frequent detection of codon 877 mutation in the androgen receptor gene in advanced prostate cancers. Cancer Res 54:28612864.

Goldblum JR and Hart WR (1997). Vulvar Paget's disease: A clinicopathologic and immunohistochemical study of 19 cases. Am J Surg Pathol 21:1178-1187.

Gottlieb B, Lehvaslaiho H, Beitel LK, Lumbroso R, Pinsky L, and Trifiro M (1998). The Androgen Receptor Gene Mutations Database. Nucleic Acids Res 26:234-238. 
Guarner J, Cohen C, and DeRose PB (1989). Histogenesis of extramammary and mammary Paget cells. An immunohistochemical study. Am J Dermatopathol 11:313-318.

Hackenberg R and Schulz KD (1996). Androgen receptor mediated growth control of breast cancer and endometrial cancer modulated by antiandrogen- and androgen-like steroids. J Steroid Biochem Mol Biol 56:113-117.

Hart WR and Millman JB (1977). Progression of intraepithelial Paget's disease of the vulva to invasive carcinoma. Cancer 40:2333-2337.

Hatta N, Takata M, Takehara K, and Ohara K (1998). Polymerase chain reaction and immunohistochemistry frequently detect occult melanoma cells in regional lymph nodes of melanoma patients. J Clin Pathol 51:597-601.

Heymann WR (1993). Extramammary Paget's disease. Clin Dermatol 11:83-87.

Imakado S, Satomi H, Ishii Y, Aiyoshi Y, and Otsuka F (1999). Lack of progesterone receptor expression in extramammary Paget's disease [letter]. Acta Derm Venereol 79:399.

Jones RE Jr, Austin C, and Ackerman AB (1979). Extramammary Paget's disease. A critical reexamination. Am J Dermatopathol 1:101-132.

Kallioniemi OP and Visakorpi T (1996). Genetic basis and clonal evolution of human prostate cancer. Adv Cancer Res 68:225-255.

Koivisto P, Kononen J, Palmberg C, Tammela T, Hyytinen E, Isola J, Trapman J, Cleutjens K, Noordzij A, Visakorpi T, and Kallioniemi OP (1997). Androgen receptor gene amplification: A possible molecular mechanism for androgen deprivation therapy failure in prostate cancer. Cancer Res 57:314-319.

Kurata S, Itami S, Komada S, and Takayasu S (1990). Intranuclear androgen and cytosolic receptor concentrations in the axillary skin of osmidrosis. Arch Dermatol Res 282:3337.

Lloveras B, Googe PB, Goldberg DE, and Bhan AK (1991). Estrogen receptors in skin appendage tumors and extramammary Paget's disease. Mod Pathol 4:487-490.

Lobaccaro JM, Lumbroso S, Belon C, Galtier-Dereure F, Bringer J, Lesimple T, Namer M, Cutuli BF, Pujol H, and Sultan C (1993). Androgen receptor gene mutation in male breast cancer. Hum Mol Genet 2:1799-1802.

Mazoujian G, Pinkus GS, and Haagensen DE Jr (1984). Extramammary Paget's disease: Evidence for an apocrine origin. An immunoperoxidase study of gross cystic disease fluid protein-15, carcinoembryonic antigen, and keratin proteins. Am J Surg Pathol 8:43-50.

Murata Y, Kumano K, and Tani M (1999). Underpants-pattern erythema: A previously unrecognized cutaneous manifestation of extramammary Paget's disease of the genitalia with advanced metastatic spread. J Am Acad Dermatol 40:949956.
Newmark JR, Hardy DO, Tonb DC, Carter BS, Epstein JI, Isaacs WB, Brown TR, and Barrack ER (1992). Androgen receptor gene mutations in human prostate cancer. Proc Natl Acad Sci USA 89:6319-6323.

Nishi M, Tashiro M, and Yoshida $H$ (1992). Stimulation of growth by both androgen and estrogen of the EMP-K1 transplantable tumor with androgen and estrogen receptors from human extramammary Paget's disease in nude mice. J Natl Cancer Inst 84:519-523.

Roth LM, Lee SC, and Ehrlich CE (1977). Paget's disease of the vulva. A histogenetic study of five cases including ultrastructural observations and review of the literature. Am J Surg Pathol 1:193-206.

Suzuki H, Sato N, Watabe $\mathrm{Y}$, Masai M, Seino S, and Shimazaki J (1993). Androgen receptor gene mutations in human prostate cancer. J Steroid Biochem Mol Biol 46:759765.

Swanson PE, Mazoujian G, Mills SE, Campbell RJ, and Wick MR (1991). Immunoreactivity for estrogen receptor protein in sweat gland tumors. Am J Surg Pathol 15:835-841.

Takahashi H, Furusato M, Allsbrook WC Jr, Nishii H, Wakui S, Barrett JC, and Boyd J (1995). Prevalence of androgen receptor gene mutations in latent prostatic carcinomas from Japanese men. Cancer Res 55:1621-1624.

Takata M, Fujimoto A, Aoki H, Hatta N, Ooi A, and Takehara K (1999). erbB-2 overexpression but no activation of betaCatenin gene in extramammary Paget's disease. J Invest Dermatol 113:258-262.

Takata M, Hatta N, and Takehara K (1997). Tumour cells of extramammary Paget's disease do not show either p53 mutation or allelic loss at several selected loci implicated in other cancers. Br J Cancer 76:904-908.

Taplin ME, Bubley GJ, Shuster TD, Frantz ME, Spooner AE, Ogata GK, Keer HN, and Balk SP (1995). Mutation of the androgen-receptor gene in metastatic androgenindependent prostate cancer. N Engl J Med 332:1393-1398.

Tilley WD, Buchanan G, Hickey TE, and Bentel JM (1996). Mutations in the androgen receptor gene are associated with progression of human prostate cancer to androgen independence. Clin Cancer Res 2:277-285.

Visakorpi T, Hyytinen E, Koivisto P, Tanner M, Keinanen R, Palmberg C, Palotie A, Tammela T, Isola J, and Kallioniemi OP (1995). In vivo amplification of the androgen receptor gene and progression of human prostate cancer. Nat Genet 9:401-406.

Yamazaki N, Yamamoto A, Wada T, Ishikawa M, Moriya Y, and Nakanishi $Y$ (1999). A case of metastatic extramammary Paget's disease that responded to combination chemotherapy. J Dermatol 26:311-316.

Zollo JD and Zeitouni NC (2000). The Roswell Park Cancer Institute experience with extramammary Paget's disease. $\mathrm{Br} J$ Dermatol 142:59-65. 